\title{
A BULBAR SUCTION TEST FOR GLAUCOMA*
}

BY

\author{
E. M. EVANS AND M. KLEIN \\ London
}

THE study of the rate of outflow of the aqueous humour from the anterior chamber of the eye has been shown to be of significance in simple glaucoma. Blaxter (1953) studied the rate of outflow in the state of strain which occurs when the intra-ocular pressure is increased by applying external pressure to the globe with Bailliart's dynamometer. It will be remembered that in Blaxter's bulbar pressure test the intra-ocular pressure (A) is first recorded using a weightless Schiötz tonometer, and the pressure is then raised by compressing the globe with Bailliart's dynamometer, exerting $50 \mathrm{~g}$. pressure over the external rectus muscle. The increased tension is recorded (B) and the two instruments are kept in place for 4 minutes, when a third reading (C) is recorded (Fig. 1).

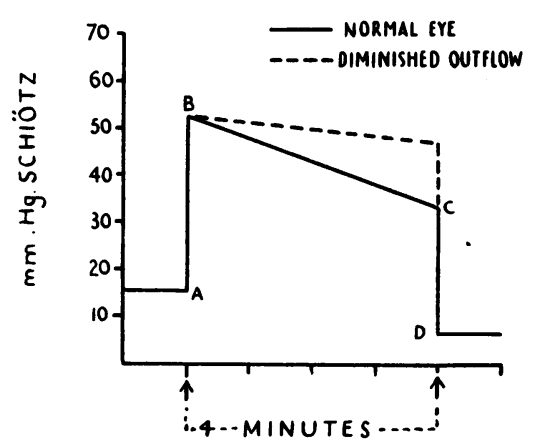

FIG. 1.-Fall in ocular tension during compression.

The outflow fraction is represented by the equation $\frac{100(B-C) \text {. }}{B}$

A fraction lower than 30 was considered to indicate diminished outflow. The use of Kukán's ophthalmodynamometer (Kukán, 1936) makes it possible to maintain increased intra-ocular pressure more accurately and conveniently.

The apparatus (Fig. 2, opposite) consists of a suction cup of $13 \mathrm{~mm}$. diameter, attached by polythene tubing and $\mathrm{T}$ junction to a vacuum manometer, and a well-greased 20-ml. syringe, the plunger of which is controlled by means 


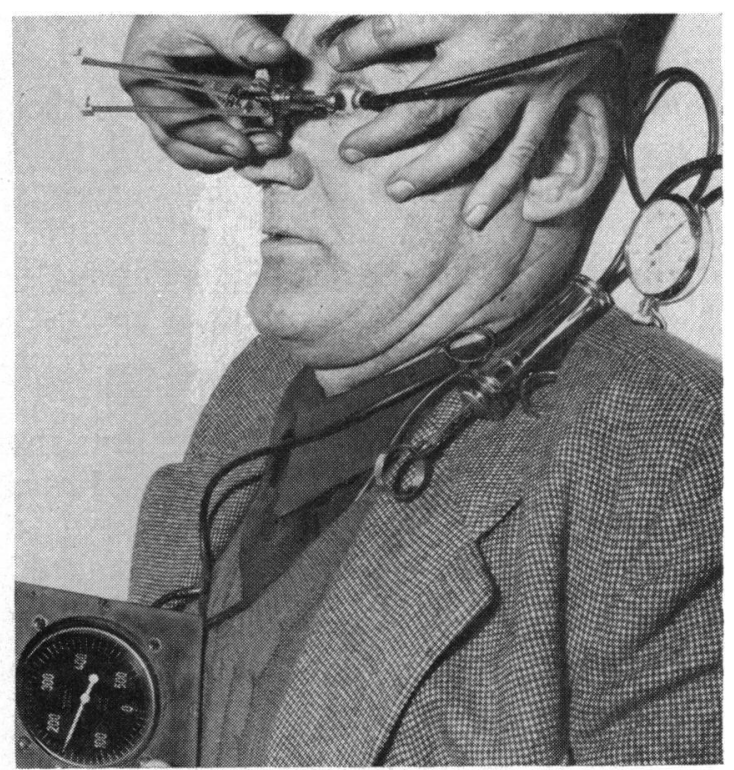

Fig. 2.-Bulbar suction test in progress.

of a screw thread. With this instrument a negative pressure of $150 \mathrm{~mm}$. $\mathrm{Hg}$ was found to produce a rise in ocular tension of the same order as that produced by Bailliart's dynamometer pressure of $50 \mathrm{~g}$., as used in Blaxter's test.

The conjunctiva is anaesthetized with 1 per cent. pantocaine, and the ocular tension measured with a weightless Schiötz tonometer. The suction cup is then applied to the sclera near the outer canthus, and a negative pressure of $150 \mathrm{~mm}$. $\mathrm{Hg}$ is induced by withdrawing the plunger which is then fixed in position by means of a screw thread. The ocular tension (B) is recorded, the tonometer is removed, and the negative pressure is raised to $165 \mathrm{~mm}$. $\mathrm{Hg}$. After 4 minutes the tension is once more reduced to $150 \mathrm{~mm}$., the tonometer is replaced, and a third tonometric reading (C) is recorded. The outflow fraction $\frac{100(B-C)}{B}$ is estimated as in Blaxter's test.

There may be some blurring of vision at the end of the test, and there is marked lowering of the intra-ocular pressure. These effects pass off in about 20 minutes.

In this test it is not necessary to maintain constant fixation, which is an advantage with uncooperative and uniocular patients, and the risk of corneal damage by prolonged tonometry is reduced. There was no evidence of corneal abrasion in any of the patients examined in this series.

When using Bailliart's dynamometer it is necessary to maintain a constant pressure normal to the globe, and this is difficult. If the dynamometer is not held in this position the effect on intra-ocular pressure is reduced. 
Moreover, as the resistance to outflow increases with increased pressure in scleral and episcleral veins, the venous congestion caused by backward pressure of the globe into the orbit may complicate the results both in Blaxter's bulbar pressure test and to a smaller degree in Grant's tonography.

Gonioscopy performed during the test on several occasions did not demonstrate any change in the angle of the anterior chamber. It has been suggested that forward movement of the lens-iris diaphragm during the bulbar pressure test of Blaxter has been responsible for irregular results in patients with shallow anterior chambers because of occasional mechanical closure of the angle (Duke-Elder, 1955).

This test was performed with ease on most patients, but it was found difficult in a few with narrow palpebral apertures. In two patients who complained of discomfort the test was abandoned.

In common with other similar tests, its accuracy is limited by the efficiency of the tonometers at present available. Moreover, the influence of scleral rigidity may be of greater importance in this test than in simple tonography, because of the relatively high pressure employed.

\section{Results}

The test was performed on thirty patients with known simple glaucoma, who had not been operated upon; and upon forty control volunteers above 50 years of age who had attended at the hospital for refraction. In the majority of patients both eyes were tested. No significant difference between the two eyes was detected, nor was there any difference in the results from male and female patients. The results are summarized in Table I and in Table II (opposite).

TABLE I

OUTFLOW FRACTION IN NORMAL SUBJECTS AND IN PATIENTS WITH CHRONIC GLAUCOMA

\begin{tabular}{|c|c|c|c|c|}
\hline \multirow{2}{*}{$\begin{array}{l}\text { Number of } \\
\text { Subjects }\end{array}$} & \multicolumn{2}{|c|}{ Controls } & \multicolumn{2}{|c|}{ Chronic Glaucoma } \\
\hline & $\begin{array}{c}\text { Right } \\
\text { Eye }\end{array}$ & $\begin{array}{l}\text { Left } \\
\text { Eye }\end{array}$ & $\begin{array}{c}\text { Right } \\
\text { Eye }\end{array}$ & $\begin{array}{l}\text { Left } \\
\text { Eye }\end{array}$ \\
\hline Total & 37 & 34 & 28 & 30 \\
\hline $\begin{array}{l}\text { Outflow Fraction Less than } 2 \mathrm{C} \\
\text { Percentage }\end{array}$ & $\begin{array}{l}2 \\
5 \cdot 4\end{array}$ & $\begin{array}{l}3 \\
8 \cdot 8\end{array}$ & $\begin{array}{l}23 \\
82 \cdot 1\end{array}$ & $\begin{array}{l}25 \\
83 \cdot 3\end{array}$ \\
\hline $\begin{array}{l}\text { Outflow Fraction } 26 \text { and Over } \\
\text { Percentage }\end{array}$ & $\begin{array}{l}29 \\
78 \cdot 4\end{array}$ & $\begin{array}{l}27 \\
79 \cdot 4\end{array}$ & $\begin{array}{l}3 \\
10 \cdot 7\end{array}$ & $\begin{array}{l}2 \\
6 \cdot 7\end{array}$ \\
\hline
\end{tabular}

It will be seen that there is a considerable difference in those obtained from the glaucomatous and control groups, but that there is also some overlap. We feel that this overlap can be explained by the experimental error which is likely to occur when a Schiötz tonometer is used, but that other factors 
TABLE II

RESULTS IN 37 CONTROL SUBJECTS AND 28 CASES OF SIMPLE GLAUCOMA

\begin{tabular}{|c|c|c|c|c|c|c|c|}
\hline \multicolumn{4}{|c|}{ Controls } & \multicolumn{4}{|c|}{ Simple Glaucoma } \\
\hline \multicolumn{2}{|c|}{ Right Eye } & \multicolumn{2}{|c|}{ Left Eye } & \multicolumn{2}{|c|}{ Right Eye } & \multicolumn{2}{|c|}{ Left Eye } \\
\hline $\begin{array}{l}\text { Initial } \\
\text { Pressure }\end{array}$ & $\begin{array}{c}\text { Outflow } \\
\text { Fraction } \\
\frac{100(B-C)}{B}\end{array}$ & $\begin{array}{l}\text { Initial } \\
\text { Pressure }\end{array}$ & $\begin{array}{c}\begin{array}{c}\text { Outflow } \\
\text { Fraction }\end{array} \\
\frac{100(B-C)}{B}\end{array}$ & $\begin{array}{l}\text { Initial } \\
\text { Pressure }\end{array}$ & $\begin{array}{c}\begin{array}{c}\text { Outflow } \\
\text { Fraction } \\
100(B-C)\end{array} \\
\text { B }\end{array}$ & $\begin{array}{l}\text { Initial } \\
\text { Pressure }\end{array}$ & $\begin{array}{c}\text { Outflow } \\
\text { Fraction } \\
\frac{100(B-C)}{B}\end{array}$ \\
\hline $\begin{array}{l}22 \\
20 \\
18 \\
20 \\
17 \\
17 \\
22 \\
20 \\
25 \\
20 \\
25 \\
20 \\
17 \\
20 \\
19 \\
19 \\
20 \\
19 \\
22 \\
19 \\
19 \\
19 \\
23 \\
16 \\
23 \\
19 \\
25 \\
16 \\
18 \\
12\end{array}$ & $\begin{array}{l}23 \\
24 \\
33 \\
29 \\
33 \\
72 \\
32 \\
27 \\
27 \\
40 \\
12 \\
23 \\
42 \\
24 \\
42 \\
27 \\
24 \\
33 \\
24 \\
32 \\
44 \\
33 \\
37 \\
42 \\
28 \\
27 \\
28 \\
27 \\
28 \\
50\end{array}$ & $\begin{array}{l}22 \\
20 \\
18 \\
20 \\
17 \\
22 \\
22 \\
21 \\
25 \\
20 \\
23 \\
20 \\
18 \\
23 \\
20 \\
22 \\
25 \\
19 \\
20 \\
23 \\
20 \\
25 \\
20 \\
17 \\
22 \\
23 \\
14 \\
29 \\
18 \\
22\end{array}$ & $\begin{array}{r}40 \\
33 \\
43 \\
42 \\
36 \\
24 \\
24 \\
44 \\
36 \\
8 \\
40 \\
32 \\
33 \\
57 \\
21 \\
40 \\
24 \\
40 \\
24 \\
28 \\
44 \\
30 \\
20 \\
32 \\
33 \\
32 \\
48 \\
18 \\
13 \\
34\end{array}$ & $\begin{array}{l}31 \\
25 \\
25 \\
23 \\
15 \\
25 \\
23 \\
23 \\
25 \\
20 \\
20 \\
21 \\
25 \\
24 \\
25 \\
25 \\
23 \\
23 \\
25 \\
22 \\
25 \\
25 \\
25 \\
19 \\
19 \\
31 \\
25 \\
25\end{array}$ & $\begin{array}{r}13 \\
0 \\
18 \\
25 \\
18 \\
12 \\
11 \\
17 \\
0 \\
13 \\
18 \\
11 \\
12 \\
30 \\
11 \\
28 \\
11 \\
18 \\
20 \\
27 \\
17 \\
12 \\
20 \\
24 \\
18 \\
12 \\
18 \\
18\end{array}$ & $\begin{array}{l}28 \\
25 \\
21 \\
25 \\
28 \\
16 \\
25 \\
23 \\
23 \\
23 \\
25 \\
23 \\
19 \\
28 \\
23 \\
25 \\
25 \\
27 \\
25 \\
25 \\
25 \\
23 \\
25 \\
21 \\
19 \\
19 \\
19 \\
25 \\
25 \\
\end{array}$ & $\begin{array}{r}18 \\
7 \\
17 \\
12 \\
11 \\
22 \\
0 \\
18 \\
7 \\
0 \\
13 \\
18 \\
18 \\
13 \\
33 \\
12 \\
23 \\
17 \\
8 \\
18 \\
11 \\
7 \\
18 \\
28 \\
0 \\
7 \\
11 \\
16 \\
23\end{array}$ \\
\hline $\begin{array}{l}12 \\
29 \\
17 \\
20 \\
16 \\
19 \\
16 \\
20\end{array}$ & $\begin{array}{l}0 \\
18 \\
27 \\
31 \\
27 \\
33 \\
33 \\
27\end{array}$ & $\begin{array}{l}16 \\
22 \\
17 \\
20\end{array}$ & $\begin{array}{l}32 \\
32 \\
33 \\
34 \\
28\end{array}$ & & $\begin{array}{l}\text { Schiötz } 19 \\
\text { Weightless }\end{array}$ & $\begin{array}{l}26 \text { Scale } \\
\text { onometer }\end{array}$ & \\
\hline
\end{tabular}

may be present. The results are illustrated in the graph (Fig. 3, overleaf). It would appear that when the test is performed in this way an outflow fraction of 20 and under is probably indicative of glaucoma, whereas a fraction greater than 25 is suggestive of a normal facility of outflow. 


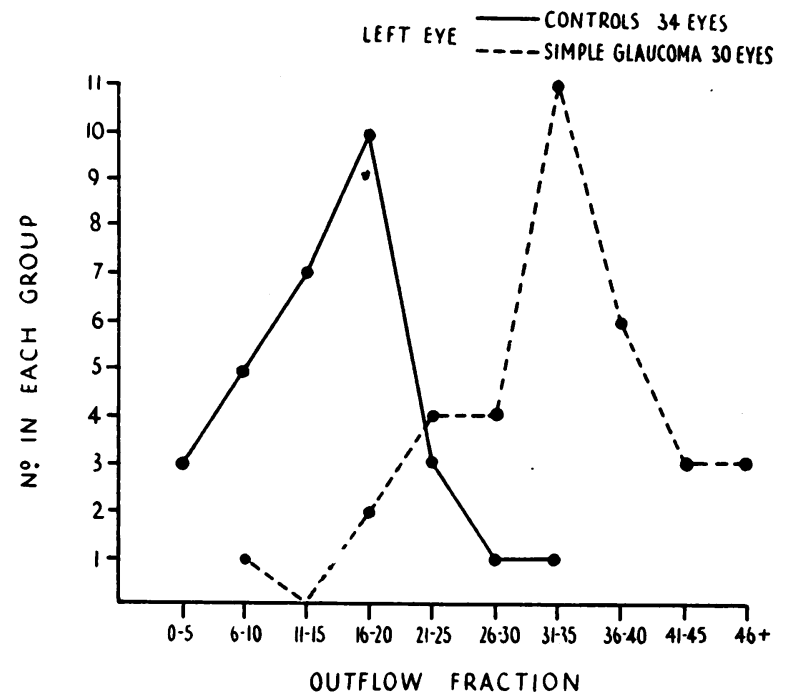

Fig. 3.-Outflow fraction in normal eyes and in eyes with simple glaucoma.

\section{Summary}

A method of assessing the rate of fall of ocular tension in the compressed globe is described. The results in normal controls and in patients with glaucoma are compared.

This work was initiated at the Glaucoma Clinic, Whipps Cross Hospital, and completed at the Institute of Ophthalmology, London. We wish to thank Sir Stewart Duke-Elder for his advice and encouragement, and the Medical Illustration Department of the Institute of Ophthalmology for preparing the illustrations.

\section{REFERENCES}

BLAXTER, P. L. (1953). Brit. J. Ophthal., 37, 641.

DUKE-ELDER, S. (1955). In "Glaucoma: A Symposium organized by the Council for International Organizations of Medical Sciences", ed. S. Duke-Elder, p. 245. Blackwell, Oxford.

KuKán, F. (1936). Z Z. Augenheilk., 90, 166.

Linksz, A. (1942). Amer. J. Ophthal., 25, 705. 